\title{
EDITORIAL
}

\section{Projeto FAPESP:}

\section{Pesquisa de Infraestrutura Verde aplicada à Cidade de São Paulo}

Prezados leitores, este número é dedicado ao Projeto FAPESP - "Infraestrutura Verde para a Resiliência Urbana às Mudanças Climáticas da Cidade de São Paulo" - para tanto foi criada uma imagem especial para a capa com um cenário futuro de uma 'São Paulo mais verde', com o incremento de áreas verdes ao longo das Avenidas Marginais e das margens do rio Pinheiros e, pasmem, a representação de uma "green bridge" (ponte verde) especial, só para pedestres, ciclistas e quem sabe de pequenos animais e da flora, saindo do Parque do Povo e cruzando o rio Pinheiros! Sabe-se que esse tipo de cenário já é comum em alguns países da Europa, e é empregado para a travessia da fauna e flora sobre rodovias que afetam zonas de preservação ambiental, mas é inédito no Brasil!

Quanto aos artigos científicos desta edição, foram selecionados cinco, dentro de temáticas afins ao Projeto FAPESP, comentados a seguir.

O primeiro artigo, de SANTOS et al, trata do mapeamento de corredores de ventilação na área de estudo, cujos
FAPESP Project:

Green Infrastructure Research applied to the City of São Paulo

Dear readers,

This issue is dedicated to the FAPESP Project "Green Infrastructure for Urban Resilience to Climate Change in the City of São Paulo" for this purpose a special graphic illustration was created for the front page of this edition - a future scenario of a 'greener São Paulo' - with the increase of green areas along the Marginal Avenues and the banks of the Pinheiros River and, believe it or not, the representation of a special green bridge, only for pedestrians, cyclists and perhaps small animals and flora, starting at Parque do Povo and crossing the Pinheiros River! It is known that such a type of scenario is already common in some European countries, and used to allow fauna and flora to cross on highways that affect areas of environmental preservation, but it is unprecedented in Brazil!

Five scientific articles were selected for the present edition, within topics related to the FAPESP Project, as below.

The first article, by SANTOS et al, deals with the mapping of ventilation corridors in the area in focus, which results 
resultados poderão servir para orientações climáticas no planejamento ambiental urbano e nas intervenções urbanísticas na área do Projeto.

MARQUES, no segundo artigo, chama a atenção para o potencial das avenidas de fundo de vale para receber intervenções de infraestrutura verdeazul, apontando para as possibilidades de uma contrapartida ambiental das infraestruturas cinza em relação ao ocultamento de córregos e ribeirões no território paulistano.

No terceiro artigo, DOBBERT et al avalia as condições térmicas do microclima do Parque Trianon (Parque Siqueira Campos) e, em paralelo, realiza entrevistas com aplicação de questionários, para medir conforto e sensação térmica e, com isso, aquilatar o grau de satisfação dos usuários em relação ao Parque.

LOCATELLI utiliza geotecnologias, no quarto artigo, para identificar áreas prioritárias para a implementação de espaços verdes na cidade de São Paulo, visando a diminuição de escoamento superficial das águas pluviais e diminuição das enchentes a jusante. Os dados obtidos foram sintetizados num mapa que aponta áreas mais indicadas para a arborização urbana, as quais ficaram concentradas nas regiões centro norte e centro sul da área de estudo. can be useful for climatic orientations in urban environmental planning and urban interventions in that Project.

MARQUES, in the second article, draws attention to the potential of valley bottom avenues to receive interventions of green-blue infrastructure, pointing out possibilities of an environmental counterpart of the gray infrastructure in relation to the hiding of creeks and streams in the territory of São Paulo City.

In the third article, DOBERT et al evaIuate the thermal conditions of Trianon Park (Parque Siqueira Campos) microclimate and, in parallel, conduct personal interviews with questionnaires to measure comfort and thermal sensation, aiming to assess the level of satisfaction of the users regarding the Park.

LOCATELLI uses geotechnologies, in the fourth article, to identify priority areas for the implementation of green spaces in the city of São Paulo, aiming at draining the superficial rainwater and reducing downstream floods. The data collected were synthesized in a map that indicates areas more suitable for the urban arborization, which were concentrated in the north-central and south-central regions of the study area. 
LOTUFO, no quinto artigo, aponta diretrizes eco-sociais para uma arquitetura integrada à infraestrutura verde, fazendo a proposição de diluir as fronteiras entre construção e paisagem, integrando edifício e infraestrutura verde e redefinindo suas funções para além do programa arquitetônico tradicional.

O Depoimento desta edição oferece um contraponto, apresentado por MARQUES, entre as proposições de infraestrutura verde aqui apresentadas nos artigos com as empregadas na cidade de Lima, no Peru. Nesse cenário, o Peru vem apresentando avanços importantes e inovadores, quanto à aplicação de conceitos tais como Infraestrutura Verde, Infraestrutura Ecológica e Sistema de Espacos Abertos, abordando tanto escalas de paisagem quanto locais, apresentando um breve panorama da utilização dos conceitos citados a partir de algumas ações e pesquisas que vem ocorrendo no país, principalmente relacionados à capital Lima.

Tenham uma boa leitura!

São Paulo, agosto de 2017.

MARIa de AssunçÃo Ribeiro Franco
LOTUFO, in the fifth article, points out eco-social guidelines for an architecture integrated with the green infrastructure, proposing to dilute the borderlines between construction and landscape, integrating green building and infrastructure as well as redefining its functions beyond the traditional architectural program.

The testimony of this edition offers a counterpoint, presented by MARQUES, among the green infrastructure proposals presented in the articles with those used in the City of Lima, Peru. In this scenario, Peru has been presenting important and innovative advances in the application of concepts such as Green Infrastructure, Ecological Infrastructure and Open Space System, focusing both landscape and local scales, presenting a brief overview of the use of the concepts mentioned from some actions and research that has been taking place in the country, mainly related to the capital Lima.

Enjoy the reading!

São Paulo, August 2017.

MARIa de Assunção Ribeiro Franco 